\title{
Effect of the cytostatic agent idarubicin on fibroblasts of the human Tenon's capsule compared with mitomycin $\mathrm{C}$
}

\author{
Claudia Heilmann, Peter Schönfeld, Thomas Schlüter, Ralf Bohnensack, \\ Wolfgang Behrens-Baumann
}

\begin{abstract}
Backgroundlaims-To investigate the in vitro effect of a short time exposure to the anthracycline idarubicin on proliferation, protein synthesis, and motility of human Tenon's capsule fibroblasts in comparison with the antitumour antibiotic mitomycin C.

Methods-After determination of effective concentrations of idarubicin, fibroblasts of the human Tenon's capsule were exposed to idarubicin or mitomycin $\mathrm{C}$ at concentrations ranging from $0.1 \mu \mathrm{g} / \mathrm{ml}$ to $1 \mu \mathrm{g} / \mathrm{ml}$ or from $2.5 \mu \mathrm{g} / \mathrm{ml}$ to $250 \mu \mathrm{g} / \mathrm{ml}$, respectively, for $0.5,2$, or 5 minutes and cultured for 60 days. Cell death by apoptosis caused by idarubicin treatment was confirmed by Hoechst 33258 staining. Further proliferation was explored by cell counting and by ${ }^{3} \mathrm{H}$-thymidine uptake. Protein synthesis was measured by ${ }^{3} \mathrm{H}-$ proline uptake and motility was assessed by agarose droplet motility assay.
\end{abstract}

Results-Idarubicin is able to exert toxicity and to induce apoptosis during a short time exposure of 0.5 minutes at concentrations of $0.3-1 \mu \mathrm{g} / \mathrm{ml}$ resulting in a significant reduction in cell number compared with the control after 60 days. For mitomycin $\mathrm{C}$, higher concentrations and longer expositions were necessary. Even after treatment with $1 \mu \mathrm{g} / \mathrm{ml}$ idarubicin or $250 \mu \mathrm{g} / \mathrm{ml}$ mitomycin $\mathrm{C}$ a few cells were able to incorporate ${ }^{3} \mathrm{H}$-thymidine. ${ }^{3} \mathrm{H}-$ proline uptake up to 10 days after exposure to $0.3 \mu \mathrm{g} / \mathrm{ml}$ idarubicin was found not to be decreased. Cell motility was reduced after treatment with $1 \mu \mathrm{g} / \mathrm{ml}$ idarubicin for 5 minutes or with $250 \mu \mathrm{g} / \mathrm{ml}$ mitomycin C for 2 or 5 minutes. For low mitomycin $C$ concentrations, an increase in motility was found during the first 10 days.

Conclusion-Idarubicin reduces proliferation of human Tenons's capsule fibroblasts after incubation for 0.5 minutes at concentrations as low as $0.3-1 \mu \mathrm{g} / \mathrm{ml}$. In comparison, mitomycin $\mathrm{C}$ requires longer exposure times and higher doses for equal results. Therefore, idarubicin may be useful in the prevention of glaucoma filtering surgery failure.

(Br F Ophthalmol 1999;83:961-966)

The goal of filtration surgery for glaucoma is to create an additional outflow channel for aqueous humour, producing a filtering bleb in the subconjunctival space. One important reason for failure is the encapsulation of the filtering bleb. Various risk factors are known including youth $^{1}$ and long term antiglaucomatous drop therapy. ${ }^{1-3}$ This scarring process is due to proliferation of fibroblasts at the site of the fistula and has been found to take place in the first 1-2 weeks after surgery. ${ }^{4}$ However, later bleb failure is also possible. ${ }^{5}$

Treatment with cytostatics has been established to reduce the proliferation of connective tissue around the bleb. Currently, mitomycin $\mathrm{C}$, an antitumour antibiotic, is usually applied on the sclera under the conjunctival flap before the sclerostomy is performed. It has been shown to induce apoptosis in human Tenon's capsule fibroblasts ${ }^{6}$ and bovine trabecular meshwork cells. ${ }^{7}$ In filtration surgery it is used in concentrations between 200 and $500 \mu \mathrm{g} / \mathrm{ml}$ during an exposure of $2.5-5$ minutes. $^{8-11}$ Although the procedure means important progress in glaucoma surgery, severe complications such as bleb leakage, ${ }^{8}$ hypotonic maculopathy, ${ }^{9}$ and impaired function of the corneal epithelium barrier ${ }^{12}$ have been reported.

With this in mind, we looked for a different cytostatic agent, which would allow a shorter intraoperative treatment of the sclera in order to reduce diffusion into neighbouring regions, where an inhibition of proliferation should be avoided-for example, the sclerocorneal limbus and the outer parts of conjunctiva. Additionally, shorter exposure times increase the comfort for patient and surgeon. We chose the anthracycline idarubicin because of its rapid entry into cells. ${ }^{13}{ }^{14}$ It accumulates in the nucleus. In haematopoetic cells, 200-300-fold differences in concentration between the nucleus and the extracellular fluid were found. ${ }^{14}$ Idarubicin binds to DNA and induces cell cycle arrest and DNA breakdown leading to apoptosis. ${ }^{15}$ In ophthalmology, idarubicin has been used for the experimental inhibition of corneal neovascularisation after alkaline burning in rabbits. ${ }^{16}$

The aim of the present study was to investigate the long term effect of idarubicin on fibroblasts of the human Tenon's capsule after short time exposure in comparison with mitomycin C. We exposed the cells to different concentrations of the drugs for 0.5-5 minutes and assessed proliferation and motility at intervals up to 60 days. Apoptosis due to idarubicin treatment was confirmed by Hoechst 33258 staining for the initial phase of the experiment.
Accepted for publication 25 March 1999 


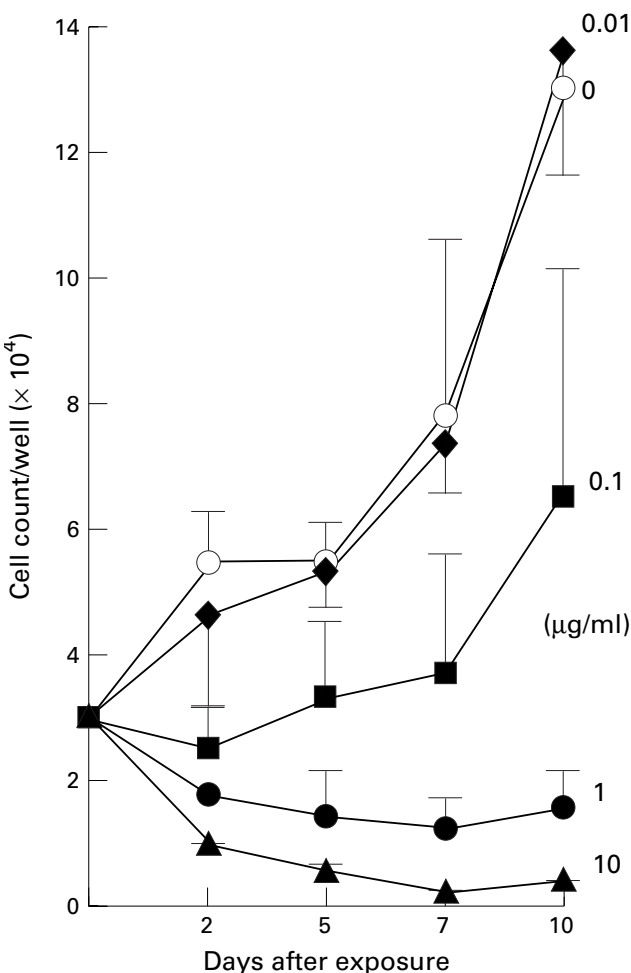

Figure 1 Effect of the idarubicin concentration on proliferation of fibroblasts of the human Tenon's capsule. To determine effective concentrations, cells of two different patients were treated in triplicate with different concentrations ranging from $0.01 \mu \mathrm{g} / \mathrm{ml}$ to $10 \mu \mathrm{g} / \mathrm{ml}$ for 5 minutes. Afterwards fibroblasts were cultured for 10 days and counted (six samples per point) at day 2, 5, 7, and 10 after exposure to idarubicin. Additional concentrations are shown in Table 1.

Additionally, we investigated the ${ }^{3} \mathrm{H}$-proline uptake 5 and 10 days after exposure to idarubicin.

\section{Materials and methods}

CELL CULTURE

Specimens of the Tenon's capsule were taken from two healthy patients during strabismus surgery. The specimens were incubated in Dulbecco's Modified Eagle's Medium (Gibco Life Technologies, Paisley) supplemented with $10 \%$ fetal calf serum (Gibco), L glutamine (200 $\mathrm{mM}$, Gibco), tylosine (100 $\mu \mathrm{g} / \mathrm{ml}$, Sigma Aldrich Chemie Deisenhofen, Germany), penicillin $(100 \mathrm{U} / \mathrm{ml}$, Boehringer Mannheim, Germany), streptomycin (100 $\mu \mathrm{g} / \mathrm{ml}$, Boeh-

Table 1 Effect of idarubicin concentration on proliferation of human Tenon's capsule fibroblasts. Cells of two different patients were treated in triplicate with idarubicin at concentrations ranging from $0.01 \mu \mathrm{g} / \mathrm{ml}$ to $20 \mu \mathrm{g} / \mathrm{ml}$ for 5 minutes and counted at day 2, 5 , 7 , and 10 after exposure. Data represent the cell count per well $\times 10^{4}$ (mean of 6 samples (SD))

\begin{tabular}{|c|c|c|c|c|}
\hline \multirow{2}{*}{$\begin{array}{l}\text { Idarubicin } \\
\text { concentration }(\mu \mathrm{g} / \mathrm{ml})\end{array}$} & \multicolumn{4}{|c|}{ Days after exposure } \\
\hline & 2 & 5 & 7 & 10 \\
\hline 0 & $5.5(0.8)$ & $5.5(0.6)$ & $7.8(2.8)$ & $13.0(0.6)$ \\
\hline 0.01 & $4.7(2.3)$ & $5.4(0.6)$ & $7.4(0.8)$ & $13.6(1.9)$ \\
\hline 0.03 & $4.1(1.1)$ & $5.1(1.0)$ & $7.9(2.5)$ & $10.8(1.0)$ \\
\hline 0.1 & $2.5(0.7)$ & $3.3(1.2)$ & $3.7(1.9)$ & $6.6(3.6)$ \\
\hline 0.3 & $1.8(0.3)$ & $2.0(0.2)$ & $1.9(0.5)$ & $2.6(2.0)$ \\
\hline 1 & $1.8(0)$ & $1.4(0.7)$ & $1.2(0.5)$ & $1.6(0.6)$ \\
\hline 2.5 & $2.1(0.9)$ & $0.9(0)$ & $0.8(0.1)$ & $0.7(0.2)$ \\
\hline 5 & $1.6(0.2)$ & $0.6(0.4)$ & $0.9(0)$ & $0.6(0)$ \\
\hline 10 & $1.0(0)$ & $0.6(0.1)$ & $0.2(0)$ & $0.4(0)$ \\
\hline 20 & $0.6(0.2)$ & $0.4(0.2)$ & $0.3(0.3)$ & $0.4(0.2)$ \\
\hline
\end{tabular}
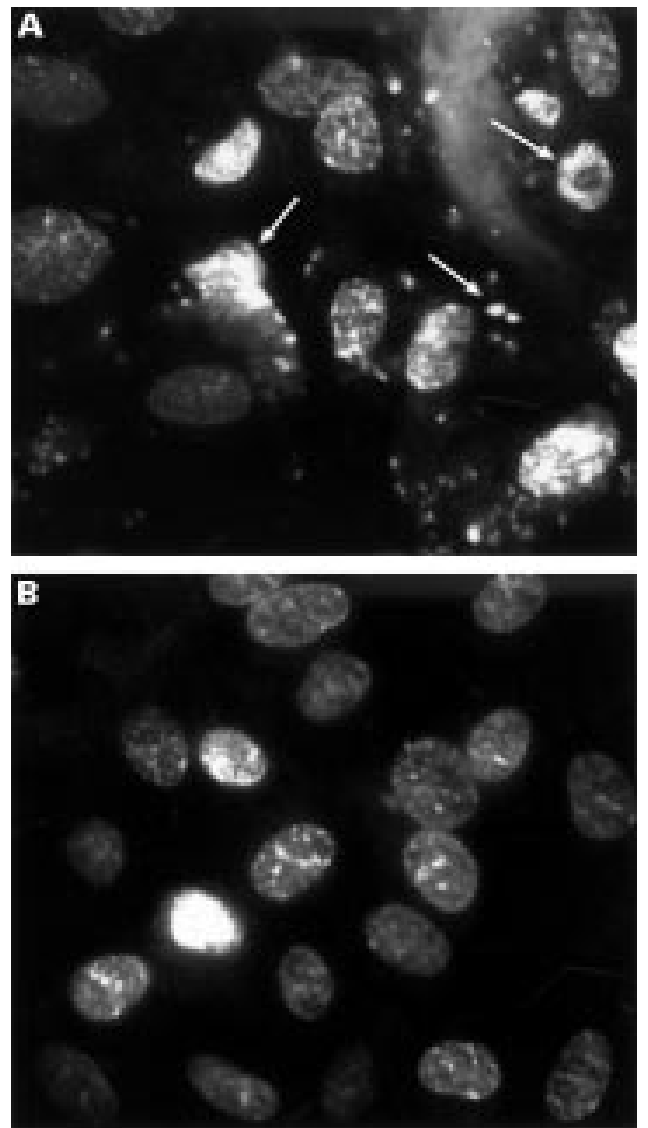

Figure 2 Assessment of apoptosis. To confirm cell death by apoptosis in the initial phase of the experiment Tenon's capsule fibroblasts were exposed to $1 \mu \mathrm{g} / \mathrm{ml}$ idarubicin for 0.5 minutes $(A)$ or to buffer $(B)$ and stained with Hoechst 33258. The cells treated with the cytostatic agent show the typical morphological feature of apoptosis with chromatine condensation, DNA fragmentation, and release of apoptotic bodies (arrows).

ringer), and glucose (30 $\mathrm{mM}$, Serumwerk Bernburg, Germany) ("medium") and processed at the same day. The pieces were chopped up, placed under coverslips in $50 \mathrm{~mm}$ petri dishes and supplied with medium. The medium was changed regularly three times a week. The antimycotics minocycline $(10 \mu \mathrm{l} / \mathrm{ml}$, Sigma Aldrich) and tiamuline $(12.5 \mu \mathrm{g} / \mathrm{ml}$, Serva Feinbiochemica Heidelberg, Germany) were added alternately. The cells were incubated at $37^{\circ} \mathrm{C}$ with $5 \%$ carbon dioxide. After reaching confluence, the cells were detached from the petri dishes with trypsin-EDTA (Gibco), centrifuged, and passaged into culture flasks. Further passages were done without minocycline or tiamuline.

DRUG TREATMENT

A total of $3 \times 10^{4}$ cells per well were placed into 24 well tissue culture plates and allowed to settle for 24 hours. Stock solutions of idarubicin (Farmitalia Milan, Italy) and mitomycin C (Sigma Aldrich) were dissolved in Hank's balanced salt solution (HBSS, $\mathrm{pH} 7.4,310$ mOsm; Gibco). After washing with HBSS, the cells were exposed to different concentrations of the cytostatics for $0.5,2$, or 5 minutes while being mildly shaken. Control groups were treated with salt solution alone. Afterwards cells were washed carefully twice with HBSS 

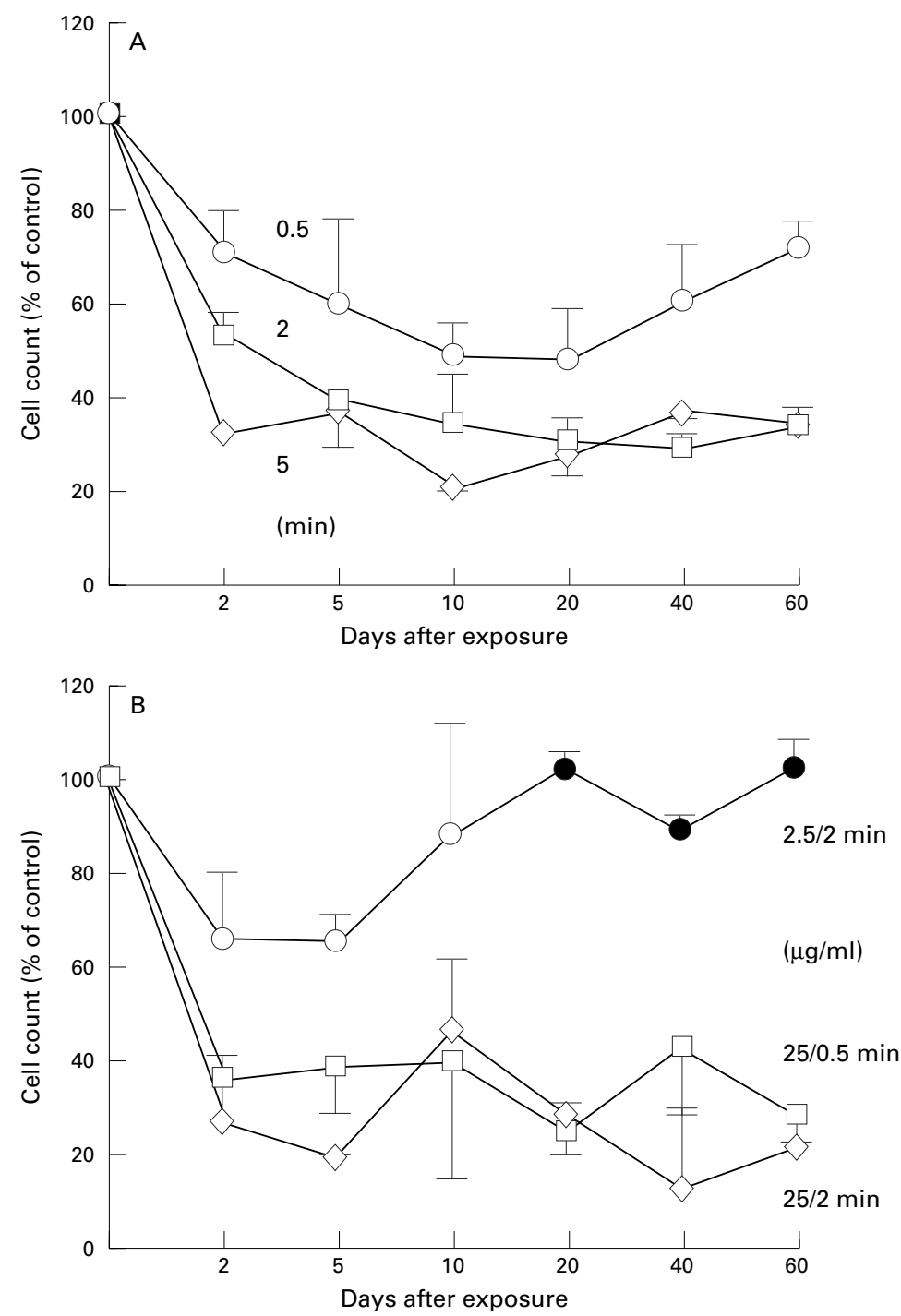

Figure 3 Comparison of the effect of idarubicin and mitomycin $C$ treatment on the proliferation of fibroblasts during long term culturing. $(A)$ Cells were exposed to $0.3 \mu \mathrm{g} / \mathrm{ml}$ idarubicin for 0.5, 2, and 5 minutes. (B) Cells were exposed to mitomycin $C$ at a concentration of $2.5 \mu \mathrm{g} / \mathrm{ml}$ mitomycin $C$ for 2 minutes or $25 \mu \mathrm{g} / \mathrm{ml}$ for 0.5 and 2 minutes. The data shown reflect the mean value of fibroblast preparations of two different patients (16 samples per point). Filled symbols, cell number not significantly reduced compared with the control $(p>0.05)$

and supplied with $1 \mathrm{ml}$ of medium. The medium was changed three times a week. The assays described below were done with cells after the indicated time of culturing.

HOECHST 33258 STAINING

Cells were harvested by trypsination, washed with HBSS, and resuspended in $250 \mu \mathrm{M}$ Hoechst 33258 (Sigma Aldrich), and dissolved in HBSS. After keeping 10 minutes on ice in the dark, the cells were centrifuged, washed, resuspended in HBSS, and photographed under a fluorescence microscope. The dye permeates membranes, stains DNA, and enables the visualisation of the nucleic morphology.

CELL COUNTING

Cells were washed with HBSS, detached by trypsin-EDTA, and counted manually using a Neubauer counting chamber (Feinoptik Blankenburg, Germany). Counting was done from each well used for one of the assays.
${ }^{3}$ H-THYMIDINE AND ${ }^{3}$ H-PROLINE INCORPORATION ASSAYS

Cell proliferation was determined by methyl${ }^{3} \mathrm{H}$-thymidine incorporation (DuPont NEN Products, Boston, MA, USA) and protein synthesis by $\mathrm{L}-2,3-{ }^{3} \mathrm{H}$-proline uptake (DuPont) according to standard protocols. Fibroblasts were incubated with medium supplemented with $0.06 \mu \mathrm{Ci}^{3} \mathrm{H}$-thymidine $(1.6 \mathrm{mM}$, specific activity $10 \mathrm{mCi} / \mathrm{mmol})$ or $1 \mu \mathrm{Ci}{ }^{3} \mathrm{H}$-proline $(17$ $\mathrm{mM}$, specific activity $2 \mathrm{mCi} / \mathrm{mmol}$ ) for 24 hours at $37^{\circ} \mathrm{C}$. The incorporation of the radioisotopes was terminated by removing the medium and carefully washing with HBSS. Cells were trypsined and a small aliquot was used for cell counting. The cells were treated with $10 \%$ sodium desoxycholate and $10 \%$ trichloracetic acid. After centrifugation, cells were washed with acetone and put in $2 \%$ SDS. One $\mathrm{ml}$ scintillation cocktail was added, followed by counting with a TRI-CARB TR 1600 liquid scintillation analyser (Packard) for 6 minutes. The assays were done in triplicate for fibroblast preparations of two different patients. ${ }^{3} \mathrm{H}$-thymidine uptake was measured for all concentrations and exposure times, ${ }^{3} \mathrm{H}$-proline uptake assay was performed 5 and 10 days after treatment with $0.3 \mu \mathrm{g} / \mathrm{ml}$ idarubicin for $0.5,2$, or 5 minutes and controls.

AGAROSE MOTILITY ASSAY

Cells were washed with HBSS, trypsined, and a small aliquot was counted. The content of each well was centrifuged. The pellets were dissolved in $5 \mu \mathrm{l}$ of $0.3 \%$ melted sea plaque agarose (Sigma Aldrich) and the droplets were transferred to the centres of wells of a 24 well tissue culture plate. In order to receive a gelatinised precoat of agarose, the plate was refrigerated at $4^{\circ} \mathrm{C}$ for 5 minutes. Droplets were covered with cooled DMEM without additions and incubated for 24 hours as stated above. Finally, the horizontal and vertical diameters of the cell patches were measured under light microscope equipped with an ocular scale. For each concentration and treatment time the experiment was performed twice for fibroblast preparations of two different patients.

For statistical comparisons, the $U$ test of the STAT-VIEW software (SAS Institute, Cary, NC, USA) was used. $\mathrm{p}<0.05$ was considered significant.

\section{Results}

EFFECTIVE CONCENTRATION OF IDARUBICIN

To determine effective concentrations of idarubicin, the dose dependent action of idarubicin on cell proliferation was measured for 10 days. The cells were incubated in triplicate for fibroblast preparations of two different patients with idarubicin at concentrations ranging from 0.01 $\mu \mathrm{g} / \mathrm{ml}$ up to $20 \mu \mathrm{g} / \mathrm{ml}$ for 5 minutes. Cells were counted at days $2,5,7$, and 10 after exposure. The cell count was significantly diminished at concentrations of $0.3 \mu \mathrm{g} / \mathrm{ml}$ and higher $(\mathrm{p}<0.05) 10$ days after exposure (Fig 1, Table 1). The further long term experiments were done with idarubicin at concentrations of 0.1 , 0.3 , and $1 \mu \mathrm{g} / \mathrm{ml}$ or with mitomycin $\mathrm{C}$ at 

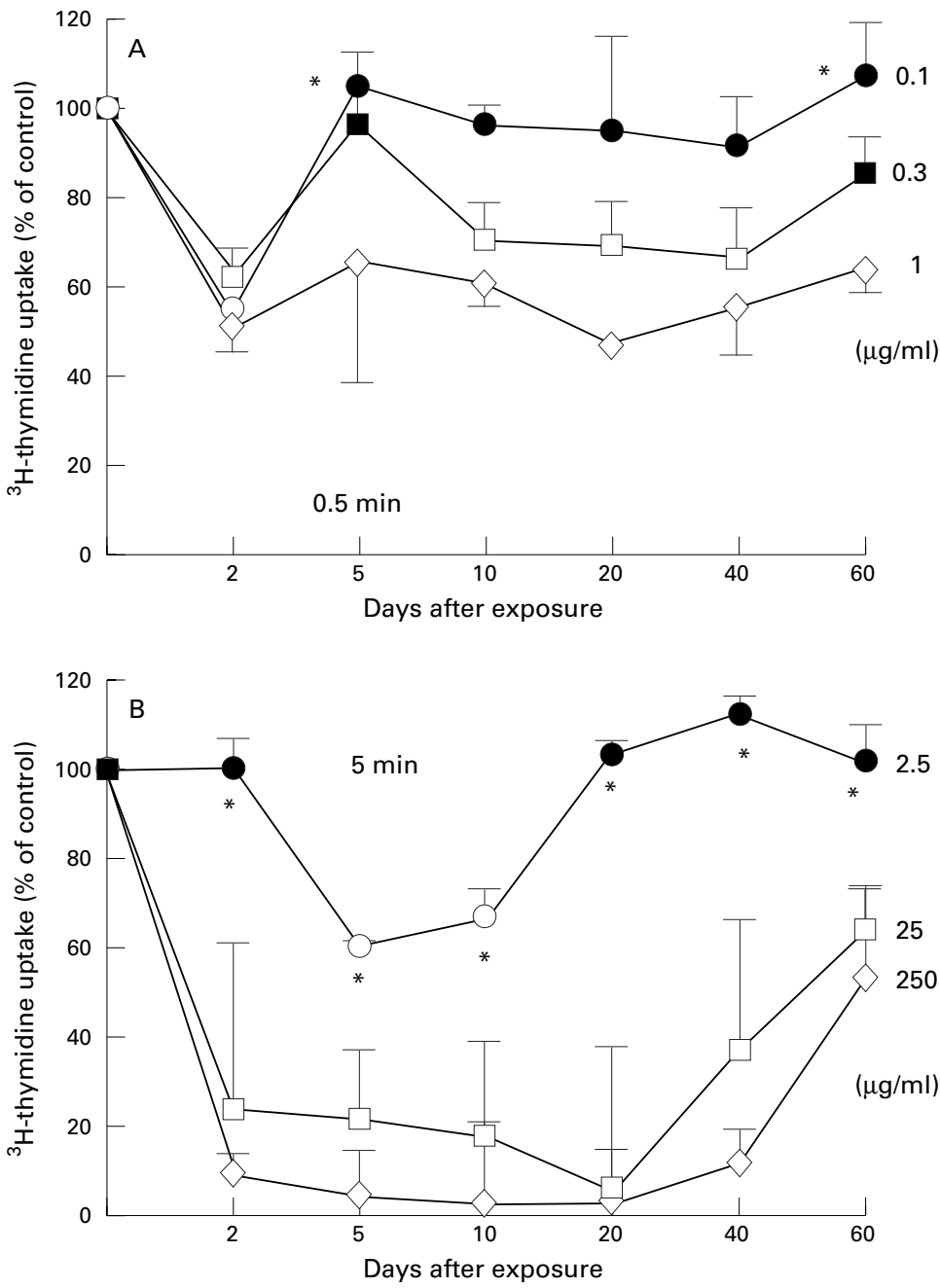

Figure 4 Effect of idarubicin and mitomycin $C$ on DNA replication. The incorporation of ${ }^{3} \mathrm{H}$-thymidine was measured for fibroblasts treated with idarubicin at concentrations of $0.1-1 \mu \mathrm{g} / \mathrm{ml}$ for 0.5 minutes $(A)$ or with mitomycin $C$ at concentrations of $2.5-250 \mu \mathrm{g} / \mathrm{ml}$ for 5 minutes $(B)$ during long term culture. The experiment was done in triplicate for fibroblast preparations of two different patients. Filled symbols, ${ }^{3} \mathrm{H}$-thymidine uptake not significantly reduced compared with the control $(p>0.05)$. Asterisks, cell number not significantly reduced compared with the control $(p>0.05)$.

concentrations of $2.5,25$, and $250 \mu \mathrm{g} / \mathrm{ml}$. The cells were exposed to the cytostatics for $0.5,2$, or 5 minutes and kept in culture for 60 days.

\section{ASSESSMENT OF APOPTOSIS}

To confirm the initial decrease in cell number is due to apoptosis caused by idarubicin treatment we exposed cells to $1 \mu \mathrm{g} / \mathrm{ml}$ idarubicin for 0.5 minutes. Cells were incubated for 48 hours and stained with the DNA dye Hoechst 33258. The cells treated with the cytostatic agent show the typical morphological feature of apoptosis with chromatin condensation, DNA fragmentation, and apoptotic bodies (Fig 2A), whereas the nuclei of control cells appear normal (Fig 2B).

\section{TIME COURSE OF INHIBITION}

Idarubicin exerts significant toxicity on fibroblasts at concentrations of $1 \mu \mathrm{g} / \mathrm{ml}$ applied for 0.5 minutes as well as $0.3 \mu \mathrm{g} / \mathrm{ml}$ (Fig $3 \mathrm{~A}$ ) and 2 or 5 minutes' exposure. These cells were able to slow reproliferation 20 days after exposure. However, proliferation stayed below that of the control ( $p<0.00160$ days after exposure). Incubation with $1 \mu \mathrm{g} / \mathrm{ml}$ during 2 or 5 minutes resulted in a breakdown of cell proliferation below $20 \%$ of control cell number 10-40 days and 10-60 days after treatment, respectively. Exposure to $0.3 \mu \mathrm{g} / \mathrm{ml}$ idarubicin for 0.5 minutes ( $<<0.005$; Fig $3 \mathrm{~A}$ ) or to $0.1 \mu \mathrm{g} / \mathrm{ml}$ for 5 minutes $(\mathrm{p}<0.005)$ or 2 minutes $(\mathrm{p}<0.0001)$ also resulted in a significant reduction of cell count compared with the control after 60 days, but the cell number stayed above $50 \%$ of the control throughout the culture period. Idarubicin at a concentration of $0.1 \mu \mathrm{g} / \mathrm{ml}$ for 0.5 minutes did not affect proliferation in a significant extent (data not shown).

Mitomycin C inhibited proliferation almost completely at a concentration of 25 and 250 $\mu \mathrm{g} / \mathrm{ml}$ at all exposure times investigated ( $\mathrm{p}$ $<0.0001$ ). At a concentration of $2.5 \mu \mathrm{g} / \mathrm{ml}$, no remarkable effect was found in comparison with the control incubation (Fig 3B).

\section{${ }^{3} \mathrm{H}$-THYMIDINE INCORPORATION}

The ${ }^{3} \mathrm{H}$-thymidine incorporation represents the ability of cells to proliferate. The control cells reached confluent growth in the wells of the culture plate between fifth and tenth day of culturing. Cells treated with idarubicin or mitomycin $\mathrm{C}$ even at the highest concentrations are able to incorporate ${ }^{3} \mathrm{H}$-thymidine after a short delay, but incubation with $1 \mu \mathrm{g} / \mathrm{ml}$ idarubicin for 0.5 minutes or with 25 or 250 $\mu \mathrm{g} / \mathrm{ml}$ mitomycin $\mathrm{C}$ for 2 or 5 minutes resulted in a significant decrease of ${ }^{3} \mathrm{H}$-thymidine incorporation up to 60 days after exposure (Fig 4A and $\mathrm{B})$.

\section{${ }^{3}$ H-PROLINE INCORPORATION}

${ }^{3} \mathrm{H}$-proline incorporation was measured in fibroblasts treated with idarubicin at a concentration of $0.3 \mu \mathrm{g} / \mathrm{ml}$. No significant decrease of uptake per cell compared with the control was found for idarubicin treated cells at days 5 and 10 after exposure to the cytostatic (data not shown).

\section{MOTILITY ASSAY}

Idarubicin decreases cell motility only at a concentration of $1 \mu \mathrm{g} / \mathrm{ml}$ applied for 5 minutes after long term culturing. Other concentrations and exposure times did not influence cell motility as assessed by agarose motility droplet assay (Fig 5A).

There is evidence that mitomycin $\mathrm{C}$ at low concentrations $(2.5 \mu \mathrm{g} / \mathrm{ml}$ for 0.5 or 2 minutes and $25 \mu \mathrm{g} / \mathrm{ml}$ for 0.5 minutes) increases cell motility throughout the first 10 days after exposure. High concentrations $(250 \mu \mathrm{g} / \mathrm{ml}$ for 2 or 5 minutes) are able to diminish cell motility during long term culturing (Fig 5B).

\section{Discussion}

The reason for failed fistulation surgery is the proliferation of connective tissue, which is triggered by inflammation following surgical trauma. This is especially important for patients, who have received long term topical antiglaucomatous therapy and are reported to have increased numbers of inflammatory cells 

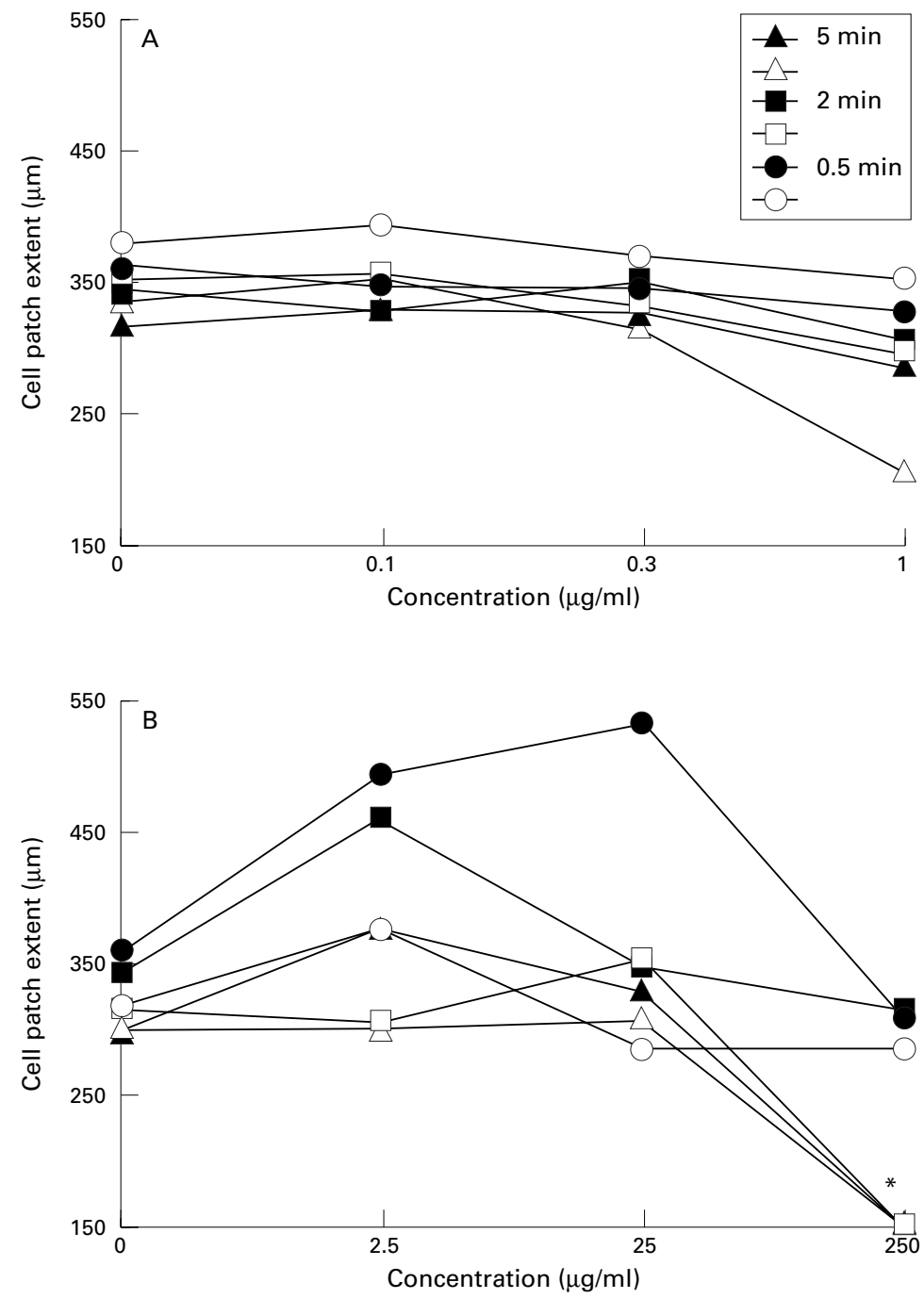

Figure 5 Effect of idarubicin and mitomycin $C$ on cell motility. Fibroblasts were exposed to idarubicin at concentrations of $0.1-1 \mu \mathrm{g} / \mathrm{ml}$ for $0.5-5$ minutes $(A)$ or to mitomycin $C$ at concentrations of 2.5-250 $\mathrm{gg} / \mathrm{ml}$ for 0.5-5 minutes (B). Motility was assessed by agarase droplet motility assay 10 and 60 days after exposure twice for fibroblast preparations of two different patients. Standard deviations ranged from $2.65 \mu \mathrm{m}$ to $117.2 \mu \mathrm{m}$, mean $44.8 \mu \mathrm{m}$ for the idarubicin experiments and from $0 \mu \mathrm{m}$ to $143.2 \mu \mathrm{m}$, mean $61.5 \mu \mathrm{m}$ for the mitomycin $C$ experiments. Filled symbols, 10 days after exposure; open symbols, 60 days after exposure. Asterisk, no cell patch.

in conjunctiva and Tenon's capsule. ${ }^{2}$ Treatment with cytostatics has been established to prevent this proliferation of the connective tissue.

The aim of our study was to define the conditions for long time suppression of fibroblast proliferation by the cytostatic idarubicin after a short application period compared with mitomycin C. For that purpose, cell cultures derived from human Tenon's capsule were exposed to idarubicin or mitomycin $\mathrm{C}$ at various conditions. Idarubicin is able to exert toxicity on fibroblasts during a short exposure of 0.5 minutes at concentrations of $0.3-1 \mu \mathrm{g} / \mathrm{ml}$ resulting in a significant reduction in cell number compared with the control after 60 days. Exposure to $0.1 \mu \mathrm{g} / \mathrm{ml}$ idarubicin for 5 or 2 minutes also resulted in a significant reduction in cell count throughout long term culturing. Idarubicin at a concentration of 0.1 $\mu \mathrm{g} / \mathrm{ml}$ for 0.5 minutes did not affect proliferation to a significant extent.
Mitomycin C inhibited proliferation almost completely at concentrations of 25 and 250 $\mu \mathrm{g} / \mathrm{ml}$ at all exposure times investigated. At a concentration of $2.5 \mu \mathrm{g} / \mathrm{ml}$, no remarkable effect was found in comparison with the control incubation. Our results for mitomycin $\mathrm{C}$ are similar to those of Khaw et al. ${ }^{17}$ In this study, mitomycin $\mathrm{C}$ was applied for 5 minutes on fibroblasts of human Tenon's capsule in vitro. A significant inhibition of proliferation compared with untreated cells was found for concentrations from $10 \mu \mathrm{g} / \mathrm{ml}$ up to $1 \mathrm{mg} / \mathrm{ml}$ for 36 days.

Recently, apoptosis due to mitomycin C treatment of human Tenon's capsule fibroblasts has been shown by Crowston et al. ${ }^{6} \mathrm{We}$ confirmed cell death by apoptosis in the initial phase after exposure to idarubicin by Hoechst 33258 staining. The drug treated cells showed the typical feature with chromatin condensation, DNA fragmentation, and release of apoptotic bodies.

The ability of the cells to proliferate after exposure to idarubicin or mitomycin $\mathrm{C}$ was measured by ${ }^{3} \mathrm{H}$-thymidine uptake. Even after treatment with $1 \mu \mathrm{g} / \mathrm{ml}$ idarubicin or $250 \mu \mathrm{g} / \mathrm{ml}$ mitomycin $\mathrm{C}$ a few cells were able to incorporate ${ }^{3} \mathrm{H}$-thymidine and to proliferate. A possible explanation is that there are cells which are insensitive to the applied cytostatic agent and are able to proliferate further. Whether these cells belong to specific clones was not detectable by our experiment; but the surviving cells were scattered on the surface of the well. Madhavan $e t$ al ${ }^{18}$ compared surgical results and sensitivity to mitomycin $\mathrm{C}$ for fibroblasts of the same patients. They postulated mitomycin C resistant cell lines, which needed higher doses of the drug compared with sensitive cell lines. The surgical outcome correlated with the evaluation of the patient's cells. Tumour cell lines not susceptible to idarubicin are also reported, but resistance to idarubicin is thought to occur less often compared with other anthracyclines. ${ }^{19}$

It is questionable whether a complete long term cut off of proliferation is an advantage considering the fine equilibrium between wound healing and avoidance of scarification of the filtering bleb.

In a study of Occleston $e t a l,{ }^{20}$ it was shown that exposure to mitomycin $\mathrm{C}$ results in an initial increase in the production of collagen type III and decreased levels of collagen type I and fibronectin throughout a 48 day culture period. McGuigan et al ${ }^{21}$ showed that daunorubicin, the parent substance of idarubicin, affects intracellular ${ }^{3} \mathrm{H}$-proline incorporation only at a very high dose, which inhibits proliferation almost completely. Extracellular incorporation remained unchanged compared with the control. Cells were incubated with daunorubicin at a concentration of $25 \mu \mathrm{g} / \mathrm{ml}$ for 48 hours. We therefore assessed the ${ }^{3} \mathrm{H}$-proline uptake 5 and 10 days after exposure to $0.3 \mu \mathrm{g} / \mathrm{ml}$ idarubicin, when the cell number was diminished to about $20 \%$ to $50 \%$ of the control, and found it had not decreased. According to these results, the remaining cells are able to produce collagens 
and the effect of the cytostatic is due to inhibition of cell proliferation and not of protein synthesis.

In our study, there was an inhibition of motility 60 days after treatment with $1 \mu \mathrm{g} / \mathrm{ml}$ idarubicin for 5 minutes or with $250 \mu \mathrm{g} / \mathrm{ml}$ mitomycin $\mathrm{C}$ for 2 or 5 minutes. For low mitomycin $\mathrm{C}$ concentrations, we even found an increase in motility in the first 10 days after application. Yamamoto et $a l^{22}$ showed that mitomycin $\mathrm{C}$ at a concentration of $10 \mu \mathrm{g} / \mathrm{ml}$ does not affect the motility of fibroblasts significantly. Again it has to be taken into consideration that the effect of the cytostatics is probably due to the reduced amount of cells.

Idarubicin diminishes the long term proliferation of fibroblasts in the human Tenon's capsule at concentrations as low as $0.3-1 \mu \mathrm{g} / \mathrm{ml}$ applied for 0.5 minutes. In comparison, mitomycin $\mathrm{C}$ requires longer applications and higher doses for equal results. Owing to the high toxicity of idarubicin, with rapid entry into the cells and little resistance, it would require only a short exposure time intraoperatively. Therefore, it could help to reduce complications resulting from a longer application of cytostatics with diffusion into neighbouring areas and to increase the comfort for patient and surgeon, and this could be useful in prevention of glaucoma filtering surgery failure.

The authors wish to thank Farmitalia, Milan, Italy for kindly supplying us with idarubicin.

This study was supported by the Deutsche Forschungsgemeinschaft, Germany (Be 1043/4-1).

1 Richter CU, Shingleton BJ, Bellows AR, et al. The development of encapsulated filtering blebs. Ophthalmology 1988;95:1163-8.

2 Sherwood MB, Grierson I, Millar L, et al. Long-term morphologic effects of antiglaucoma drugs on the conjunctiva and Tenon's capsule in glaucomatous patients. Ophthalmoland Tenon's capsule in

3 Lavin MJ, Wormald RPL, Migdal CS, et al. The influence of prior therapy on the success of trabeculectomy. Arch Ophthalmol 1990;108:1543-8.

4 Jampel HD, McGuigan LJB, Dunkelberger GR, et al. Cellular proliferation after experimental glaucoma filtration surgery. Arch Ophthalmol 1988;106:89-94.
5 Scott DR, Quigley HA. Medical management of a high bleb phase after trabeculectomies. Ophthalmology 1988;95: 1169-73.

6 Crowston JG, Akbar AN, Constable PH, et al. Antimetabolite-induced apoptosis in Tenon's capsule fibroblasts. Invest Ophthalmol Vis Sci 1998;39:449-54.

7 Sibayan SAB, Latina MA, Sherwood ME, et al. Apoptosis and morphologic changes in drug-treated trabecular meshwork cells in vitro. Exp Eye Res 1998;66:521-9.

8 Kitazawa Y, Kawase K, Matsushita H, et al. Trabeculectomy with mitomycin. A comparative study with fluorouracil. Arch Ophthalmol 1991;109:1693-8.

9 Jampel HD, Pasquale LR, Dibernardo C. Hypotony maculopathy following trabeculectomy with mitomycin C. Arch Ophthalmol 1992;110:1049-50.

10 Schwartz AL, Weiss HS. Bleb leak with hypotony after laser suture lysis and trabeculectomy with mitomycin C. Arch Ophthalmol 1992;110:1049.

11 Yaldo MK, Stamper RL. Long-term effects of mitomycin on filtering blebs. Arch Ophthalmol 1993;111:824-6.

12 Tanihara H, Yokoi N, Komuro A, et al. Prolonged impairement of peripheral corneal epithelium barrier function after successful trabeculectomy. Am f Ophthalmol 1997; 123:487-93.

13 Berman E, McBride M. Comparative cellular pharmacology of daunorubicin and idarubicin in human multidrugresistant leukemia cells. Blood 1992;79:3267-73.

14 Gieseler F, Biersack H, Brieden T, et al. Cytotoxicity of anthracyclines: correlation with cellular uptake, intracellular distribution and DNA binding. Ann Hematol 1994;69: S13-S17.

15 Smith PJ, Rackstraw C, Cotter F. DNA fragmentation as a consequence of cell cycle traverse in doxorubicin- and idarubicin-treated human lymphoma cells. Ann Hematol 1994;69:S7-S11.

16 Rothe M. Die Wirkung von Idarubicin (4Demethoxydaunorubicin) auf die Neovaskularisation der Kaninchenhornhaut nach experimentell induzierter Laugenverätzung. Medical doctoral thesis 1992 Göttingen, Germany.

17 Khaw PT, Sherwood MB, MacKay SLD, et al. Five-minute treatments with fluorouracil, floxuridine and mitomycin have long-term effects on human Tenon's capsule fibroblasts. Arch Ophthalmol 1992;110:1150-4.

18 Madhavan HN, Rao SB, Vijaya L, et al. In vitro sensitivity of human Tenon's capsule fibroblasts to mitomycin c and its correlation with outcome of glaucoma filtration surgery. Ophthalmic Surg 1995;26:61-7.

19 Testi R, Mattii L, Di Simone D, et al. Evaluation of resistance index of several anticancer agents on parental and resistant P-388 cell lines. Leuk Res 1995;19:257-61.

20 Occleston NL, Daniels JT, Tarnuzzer RW, et al. Single exposures to antiproliferatives. Long-term effects on ocular fibroblast wound-healing behavior. Invest Ophthalmol Vis Sci 1997;38:1998-2007.

21 McGuigan LJB, Quigley HA, Lutty G, et al. The effects of d-penicillamin and daunorubicin on conjunctival fibroblast proliferation and collagen synthesis. Invest Ophthalmol Vis Sci 1988;29:112-8.

22 Yamamoto T, Varani J, Soong HK, et al. Effects of 5-fluorouracil and mitomycin c on cultured rabbit subconjunctival fibroblasts. Ophthalmology 1990;97:1204-10. 